\title{
Research on the Innovation of Enterprise Financial Management Based on the Internet
}

\author{
Kang Yong ${ }^{1}$ \\ ${ }^{1}$ Henan Institute of Economics and Trade, Zhengzhou City, Henan Province, 450018
}

Key words: Internet; Enterprise Financial Management; Innovation

\begin{abstract}
: with the development of network technology, the survival environment of enterprises has changed significantly, and many traditional business methods are gradually being replaced by electronic shopping, electronic payment and other electronic commerce, which has led to a great change in the environment of enterprises financial management. At present, many enterprises are faced with financial management problems, which seriously restricts the sustainable development of enterprises. Therefore, the reform of enterprise financial management model is very necessary. Based on the author's many years of work experience, firstly, this paper analyzes the significance of the transformation of enterprise financial management under the network environment, then it discusses the main problems faced by enterprises in the process of financial management transformation, at last, it puts forward the strategies of enterprise financial management innovation under the network environment.
\end{abstract}

\section{Introduction}

The Internet industry with a powerful information and service function is changing the social from all walks of life and various fields. Global and digital economic network bring new opportunities and challenges to the enterprises to participate in market competition, playing a promoting role in enterprise management. As an important part of enterprise management, financial management is faced the challenges whether themselves can quickly keep up with new technologies and adapt to the Internet. The author believes that in the Internet era, the traditional financial management has many drawbacks, only in time for financial management innovation, can enterprises take the initiative in the domestic and foreign market competition.

\section{The Importance of Enterprise Financial Management Transformation in the Network Environment}

It is the need for enterprises to adapt to the external environment changes. Network economy is a new economic form based on computer network and information technology is its core. The network economy not only contains the information technology industry which takes the computer as the core, but also includes the revolutionary change of the traditional industry which is brought by the popularization and application of the high technology. With the gradual formation of the global network, many business activities are in the form of Electronic Commerce on the Internet, which has brought the change of enterprise marketing activities, business model, organizational form. The establishment of online banking provides a more reliable financial guarantee for the economic operation, which has a direct impact on the financial management of enterprises. In the network environment, the enterprise's raw material procurement, cargo shipping, tax returns can be 
carried out on the Internet, which will undoubtedly put forward a new challenge to the enterprise financial management mode. Therefore, it is necessary to promote the reform of enterprise financial management system, in order to adapt to the development requirements of the network economy.

It can enhance the competitiveness of enterprises. Network financial management is a kind of new financial management mode, and it applies network technology to financial management, which can solve many new problems that can't be solved by traditional financial management, such as inter regional accounting statements, dynamic financial analysis, financial data transmission. Network financial management achieves the financial and business collaboration management, online management, dynamic accounting and online economic resource management. Network finance has the characteristics of quick and safe. Network finance greatly reduces the physical distance between the two sides of the transaction, to achieve the management of business and financial management. Network finance is conducive to the rapid adjustment of marketing strategy, integration of various resources, improving the market share of products. Through the network finance, it can monitor the operating conditions of the enterprise at any time, so it can reduce the generation of false information, improve the accuracy of financial statements, and provide a more reliable basis for decision-making.

Network finance helps enterprises to reduce the cost of trading, capital, enterprise operation and so on. In the network finance, the use of electronic money can shorten the circulation of funds and improve the capital turnover rate. Through online procurement, payment, settlement, enterprises reduce the cost of traditional procurement and avoid the cost of marketing is too high. Through electronic commerce transactions, accounting, it can more accurately reflect the financial situation of enterprises, to achieve business and financial synchronization. At the same time, the network finance is helpful for the enterprise to use the network system to coordinate the enterprise report, the quotation, the tax payment, the transfer and so on, which will reduce the management cost. The wide application of network technology brings revolution in financial management, which makes up for the deficiency of traditional accounting methods, and expands the scope of business.

\section{The Main Problems Faced by Enterprises in the Process of Financial Management Innovation}

Difficult to guard against the risk of enterprise financial management. Network is open, so it is easy to be stolen in the process of information transmission, test and interception, which has brought great security risk to the enterprise financial management. For businesses, its financial management, especially financial data belongs to major companies trade secrets, once destroyed, leak, it will bring significant losses to the enterprise. Traditional enterprise financial management is conducted in the enterprise software for the internal LAN, so there is no security risks and threats. In the network environment, online corporate financial management must first address network security issues. Identity confirmation and document management issues. Network economy has brought changes in the form of commercial transactions. Without meeting, both parties can perform normal e-commerce transactions. Traditional financial management commonly used handwritten signature, but in the Internet environment, the more use is electronic contracts and other non-paper media, which makes traditional signature approach has been a great challenge. Currently, e-commerce is an important means of exchange, however, legal norms and technical support system and network economy to adapt has not been established, transaction security can not be effectively protected, it also brings to the enterprise financial management a number of risks that are difficult to guard against. 
Difficult to meet the demand of electronic commerce. A series of operations in e-commerce is completed on the Internet, achieving a transaction virtualization and real-time, which undoubtedly brings a series of challenges to the traditional financial management. Traditional financial management tools do not implement online office, so budgeting and decision-making take a long time to wait, unable to adapt to e-commerce development needs. Traditional financial control and analysis of the way can not meet demand of e-commerce, because under the conditions of the network economy, enterprise asset structure has undergone great changes, and the importance of intangible assets patents, trademarks, product innovation has become increasingly prominent, but the traditional financial management content main concern is tangible assets, intangible assets less attention, lack of intangible assets in the actual effective financial management activities estimates and operations management, which brings financial management issues. In the network economy, the financial data processing and management of financial resources of the subsidiary bodies, enterprises are using centralized processing model, but the traditional financial processing mainly uses decentralized management model, which resulted in inefficiency, inadequate control of the subsidiary bodies and other issues. Thus, the traditional financial management system has not adapted to the needs of e-commerce operation.

Encounter new challenges on management model. The Internet has changed the business of trading patterns and financial management models, making raw material procurement, product sales, consignment and a series of procedures can be completed online, these changes requires the financial management of the enterprise change accordingly, can handle a variety of electronic documents, electronic money, pages data. But traditional financial management using the intranet, it could not automatically carry out the financial management, only managed online through an internal network, which led to a lot of limitations. Traditional financial software managers are required to work on the intranet, which is very different from the way the office network economy, this change from the internal network to the Internet revolution is undoubtedly the way of the financial office. From the work point of view, the new financial management requires management platform to support online office, mobile office, capable of handling electronic money, web pages and other data, this is a challenge to the traditional financial system.

\section{The Innovation Strategies of Enterprise Financial Management under the Network Environment}

Establish and improve the enterprise financial risk early warning mechanism. After China's accession to the WTO, it gradually joins in the world economy, so the risks and uncertainties of the enterprises are greatly increased. Enterprise falling into the difficult situation caused by the financial crisis is often seen. Therefore, the establishment of enterprise financial risk early warning mechanism, in time to prevent and resolve the financial crisis of the enterprise, it is very necessary. In specific operations, through the financial statements, financial data, companies analyze Enterprise Financial problems in the operation of risks, in order to make early prevention work. At the same time, companies must constantly change the concept of financial management, comprehensively use computer and network technology to establish financial early warning mechanism, develop a new model of financial management can adapt to the needs of enterprise management.

Improve enterprise network information security system. Network information security is a complex system engineering, involving the system, network, application, management and other aspects, it should use a variety of security measures. However, many companies did not use a dedicated network management personnel, enterprise network security management work is not in 
place, more security vulnerabilities, at the same time, network maintenance and operation is also a heavy work, and its operating costs are high. These difficulties lead to the enterprise network security management have many problems. Therefore, enterprises should actively promote the construction of enterprise network security system, make the legal policy of network management and operation, and use the law to provide security for the network security. Establish information security management mechanism, strengthen the education of information security management, training, improve the comprehensive quality of financial management. Establish a firewall between the intranet and the Internet in order to prevent the computer virus from attacking. At the same time, digital signature technology should be applied to the identity authentication of electronic commerce, in order to prevent illegal entry, to provide security for financial management.

Improve the enterprise internal management system. The traditional enterprise is a pyramid structure, and financial management department and business department are independent of each other, limited by the scope of management, there are many middle management. Under the condition of network economy, the market environment and business models have undergone tremendous changes, Market of enterprise information feedback ability put forward higher requirements, requiring the enterprises to carry on the information-based transformation to the management system, therefore, enterprises should strengthen the information, network management. At the same time, computer technology, information technology should be applied to the financial management of enterprises, gradually to realize the computerized accounting, improve the efficiency of enterprise management and business accuracy, reduce business transaction costs.

\section{Conclusion}

With the rapid development of the network economy, financial management will undergo profound changes, promoting financial management model innovation has become an inevitable trend of the development of financial management. Facing the opportunities and challenges in financial management, we must continue to improve management practices and promote innovation and the development of financial management.

\section{References}

[1] Jiang Shijin, Zhang Meijuan, Shi Biao. Financial management innovation based on Internet [J]. finance and accounting monthly, 2008,02:89-91.

[2] Liu Jun. Financial management innovation under the network economy [J]. modern finance and Economics - Journal of Tianjin Institute of Finance and economics, 2003,01:37-40.

[3] Liu Yuhong. Financial management innovation in e-commerce environment [J]. China business, 2011,20:95-96.

[4] Liu Yuetian, Zhang Huiping. The change of financial management in the information age [J]. Journal of Shanxi University of Finance and Economics, 2010, S2:249+258.

[5] Wang Aihua. Construction of Internet financial management standard system research [J]. financial and accounting communication, 2004,12:87-90. 